\title{
Aplikasi Pembayaran Iuran Bulanan Pada TPQ As-Salam Sumbawa Berbasis Android
}

\author{
Shinta Esabella ${ }^{1,}$, Habib Shibghatallah ${ }^{2}$, Fahri Hamdani ${ }^{3}$ \\ ${ }_{1,2,3}$ Program Studi Teknik Informatika, Universitas Teknologi Sumbawa, Nusa Tenggara Barat, Indonesia \\ Email: ${ }^{1, *}$ shinta.esabella@uts.ac.id, ${ }^{2}$ Habib@uts.ac.id, ${ }^{3}$ Fahri@uts.ac.id
}

$\begin{aligned} & \text { INFORMASI ARTIKEL } \\ & \begin{array}{l}\text { Sejarah Artikel: } \\ \text { Diterima Redaksi } \\ \text { Revisi Akhir }\end{array} \\ & \begin{array}{l}\text { Diterima } \\ \text { Diterbitkan Online }\end{array} \\ & : 20 \text { November } 2021 \\ & : 28 \text { November } 2021\end{aligned}$
KATA KUNCI
Android,
RAD,
Black box,
rest API
KORESPONDENSI
E-mail: shinta.esabella @ uts.ac.id

\begin{abstract}
A $\quad$ B $\quad \mathbf{S}$ T $\mathbf{R}$ A $\mathbf{C}$ T
Pembayaran iuran adalah pembayaran setiap bulan dari murid yang menjadi kewajiban bagi murid di sekolah. Pembayaran iuran tersebut diambil berdasarkan kesepakatan rapat Komite sekolah dan orangtua murid. Tujuan dari penelitian ini adalah untuk mempermudah sistem pembayaran iuran yang ada pada TPQ Assalam. Penelitian ini menggunakan metode pengembangan perangakat lunak Rapid Application Development (RAD) dan black box sebagai alat penguji aplikasi. Metode pengumpulan data menggunakan observasi, wawancara, dokumentasi, studi pustaka dan kuesioner. Aplikasi pembayaran iuran bulanan pada TPQ As-salam ini menggunakan rest API, rest API digunakan untuk mengambil data dan menyimpan data di dalam database online. Adapun database yang digunakan pada aplikasi ini yaitu MySQL versi 5.1
\end{abstract}

\section{PENDAHULUAN}

Teknologi di era saat ini telah memudahkan serta mempercepat aktifitas kehidupan manusia baik itu dibidang politik, ekonomi dan pendidikan, salah satu teknologi yang banyak digunakan manusia yaitu smartphone. Smartphone atau disebut telepon genggam merupakan teknologi informasi dan komunikasi mutakhir yang memiliki banyak fitur canggih layaknya sebuah komputer. Peran teknologi dalam pendidikan sangat penting, dengan adanya teknologi ini dapat meningkatkan kualitas pendidikan dan menjadikan instansi pendidikan memiliki mutu yang tinggi. Taman pendidikan Al-Quran atau TPQ merupakan pendidikan yang bergerak di bidang kerohanian untuk mempelajari dasardasar membaca Al-Quran salah satunya yaitu TPQ As-salam, TPQ As-salam memulai kegiatan belajar mengajar pada tahun 2019 dan beralamat di Jl. Bypass Sering, Kerato, Unter Iwes, Kabupaten Sumbawa, Nusa Tenggara Barat. Memiliki kurang lebih 40 murid mulai dari usia 5 sampai 14 tahun. Dalam dunia pendidikan terdapat suatu biaya pendidikan atau sering disebut SPP dan juga uang iuran berfungsi untuk berlangsungnya kegiatan pendidikan di suatu lembaga pendidikan, uang iuran merupakan sumber dana yang berasal dari orang tua.

Sistem pembayaran yang ada di TPQ As-salam masih menggunakan sistem manual dengan kartu iuran murid dan buku iuran murid sebagai media penyimpanannya. Proses pembayaran ini mengakibatkan kartu dan buku iuran 2 murid sering diganti dikarenakan data yang sudah penuh atau terjadinya kehilangan kartu iuran murid, tentu dengan hal tersebut menimbulkan hambatan dalam proses pembayaran iuran bulanan. Berdasarkan hasil wawancara dan kuesioner yang telah dilakukan oleh peneliti, dapat disimpulkan bahwa, TPQ As-salam menginginkan sebuah sistem yang dapat menggantikan sistem yang ada saat ini, suatu sistem pembayaran iuran yang dapat memudahkan dan mempercepat prosesnya, wawancara dilakukan dengan pimpinan TPQ As-salam. Dari hasil kuesioner yang dilakukan oleh peneliti dapat disimpulkan bahwa 28 wali murid dari 34 wali murid setuju untuk dibuatkannya aplikasi pembayaran iuran TPQ As-salam.

Oleh karena itu, peneliti membuat aplikasi pembayaran iuran bulanan berbasis Android di TPQ As-salam sumbawa. Aplikasi pembayaran iuran bulanan dengan tempilan halaman user sebagai akun murid dan halaman admin sebagai pengelola pendidikan dengan begitu orangtua murid dapat mengetahui informasi pembayaran iuran bulanan dengan cepat dan pengelola dapat mengelola data pembayaran dengan mudah 


\section{METODOLOGI PENELITIAN}

Metodologi pada penelitian ini yaitu sebagai berikut:

\subsection{Metode penelitian}

Metode penelitian yang digunakan dalam penelitian ini adalah mixed method. mixed method merupakan pendekatan penelitian yang mengkombinasikan atau menggabungkan bentuk kualitatif dan kuantitatif [1].

\subsection{Metode Pengembangan Perangkat Lunak}

Metode RAD merupakan metode pengembangan aplikasi yang lebih cepat dan efektif[2]. Adapun tahapan dari RAD dapat diuraikan sebagai berikut [3]:

a. Requirements planning

Pada tahap ini, penganalisis dan pengguna bertemu untuk melakukan identifikasi dari tujuan aplikasi, pengguna terdiri dari admin dan user. Adapun tahapan pengumpulan data dalam penelitian ini dapat diuraikan sebagai berikut :

1. Observasi

Observasi dilakukan dengan cara mengamati secara langsung proses yang terjadi di tempat penelitian.

2. Wawancara

Wawancara dilakukan dengan cara memberikan beberapa pertanyaan yang sudah terstruktur kepada pengelola dan pimpinan di TPQ As-salam.

\section{Studi pustaka}

Pustaka Studi pustaka dilakukan dengan cara mengumpulkan informasi dan data dari berbagai macam material yang ada di perpustakaan atau di internet.

4. Dokumentasi

Dokumentasi dilakukan dengan cara memperoleh data dan informasi dari tempat penelitian berupa kartu iuran dan buku iuran.

\section{Kuesioner}

Kuesioner dengan cara menyebarkan angket atau kuesioner kepada wali murid yang ada di TPQ Assalam.

\section{b. RAD design workshop}

Pada tahap ini, dilakukan perancangan terhadap proses pembayaran iuran bulanan TPQ As-salam, perancangan ini bertujuan untuk menunjukkan representasi visual desain dan pola kerja kepada pengguna. Adapun tampilan perancangan pembayaran iuran bulanan TPQ As-salam terdiri dari tampilan user dan admin.

c. Implementation

Pada fase implementasi ini, dilakukan pengujian terlebih dahulu terhadap aplikasi yang sudah dirancang kepada pengguna, jika terdapat masalah pada aplikasi maka akan dilakukan perbaikan. Setelah dilakukan perbaikan aplikasi tersebut layak untuk digunakan oleh pengguna.

\subsection{Flowmap yang Berjalan}

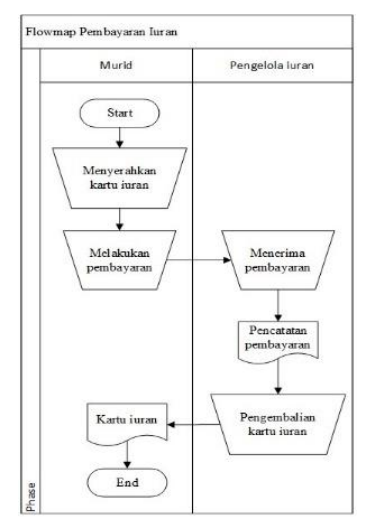

Gambar 1. Flowmap yang berjalan 
Dapat diketahui bahwa flowmap pembayaran iuran yang berjalan pada TPQ As-salam saat ini masih manual dapat dilihat pada gambar flowmap dibawah ini :

\subsection{Flowmap yang Diusulkan}

berikut ini flowmap yang diusulkan yakni sebagai berikut :

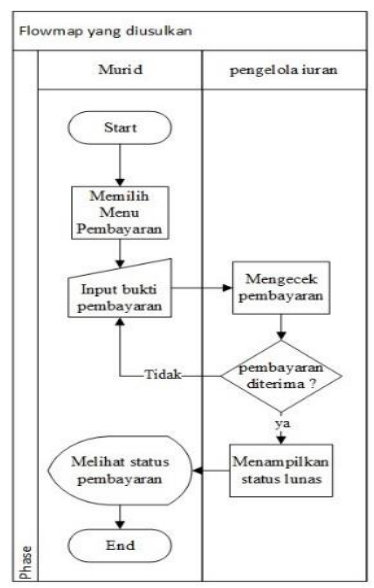

Gambar 2. Flowmap yang diusulkan

\subsection{Perangkat Pengguna Sistem}

Perangkat pengguna sistem yaitu perangkat keras dan perangkat lunak yang dapat dilihat pada tabel di bawah ini:

Tabel 1. Perangkat Pengguna Sistem

\begin{tabular}{ll}
\hline Perangkat & Spesifikasi \\
\hline Perangkat keras & a. RAM 1 GB \\
& b. Internal memory 8GB \\
Perangkat lunak & Sistem operasi : android 6.0 \\
\hline
\end{tabular}

\section{ANALISA DAN PEMBAHASAN}

\subsection{Analisa}

Analis dan pembahasan pada penelitian ini dapat diuraikan sebagai berikut :

\subsection{Diagram Context}

Diagram context menggambarkan proses secara garis besar apa yang terjadi pada program aplikasi ini. Adapun diagaram context pembayaran iuran ini adalah sebagai berikut :

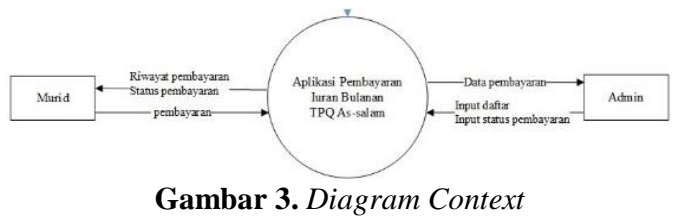

Dapat dijelaskan bahwa aplikasi pembayaran iuran bulanan TPQ As-salam murid dapat melakukan pembayaran, melihat riwayat pembayaran dan melihat status pembayaran, kemudian admin dapat melihat riwayat pembayaran murid, melakukan input status pembayaran murid dan kemudian admin juga dapat melakukan daftar untuk membuat akun murid

\subsection{Data Flow Diagram}

Data flow diagram dalam perancangan ini menggambarkan suatu jaringan kerja dari proses penyimpanan data. Adapun gambar data flow diagram adalah sebagai berikut : 


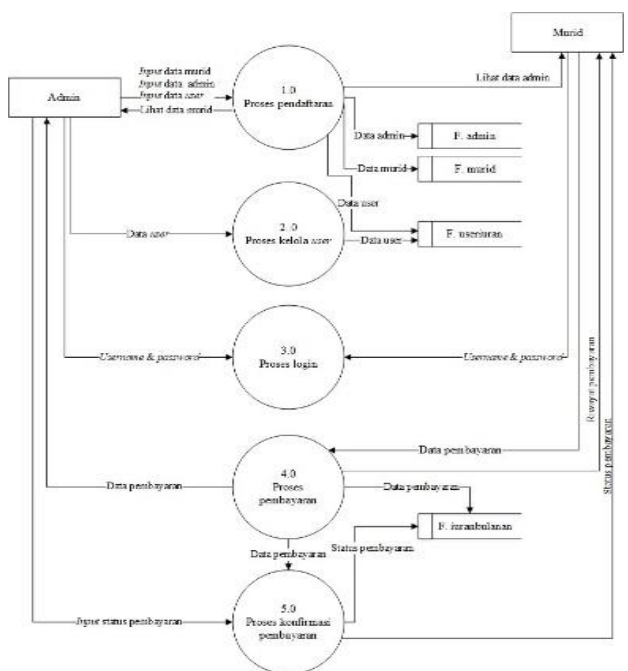

Gambar 4. Data Flow Diagram

Dapat dijelaskan bahwa pembayaran. pada proses pendaftaran admin akan menginput data admin, data murid dan data user yang nantinya data tersebut akan disimpan dalam file admin, file murid dan file useriuran kemudian data admin akan dilihat oleh murid. Data user dapat dikelola oleh admin dimana data tersebut akan disimpan dalam file useriuran, setelah admin melakukan proses pendaftaran maka murid dapat melakukan proses login. Dalam proses pembayaran, murid akan menginput data pembayaran dan data pembayaran tersebut dapat dilihat oleh admin kemudian data pembayaran akan diproses untuk melakukan konfirmasi pembayaran dari data tersebut admin akan menginput status pembayaran dan status pembayaran akan sampai kepada murid.

\subsection{Entity Relationship Diagram}

Entity relationship diagram (ERD) digunakan untuk menyatakan hubungan antar entitas. Adapun ERD yang digunakan sebagai berikut :

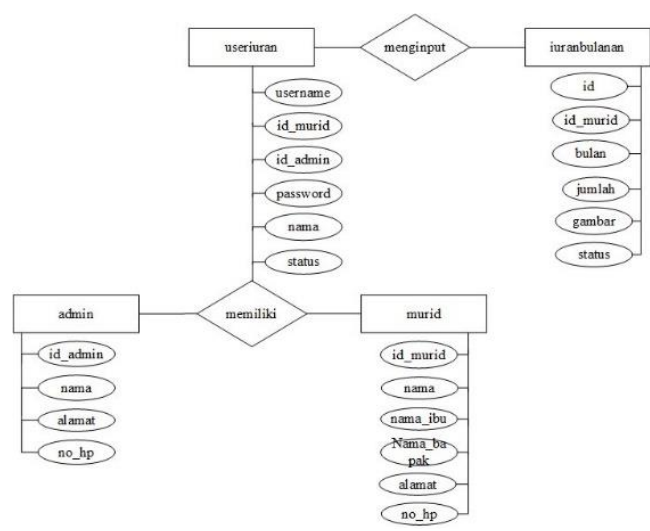

Gambar 1. Entity Relationship Diagram

\subsection{Pembahasan}

Dengan hasil tersebut, dapat dikatakan bahwa tujuan dari penelitian ini sudah tercapai, yaitu membantu pengelola iuran dan wali murid untuk melakukan pembayaran iuran bulanan. Hasil penelitian ini juga sesuai dengan penelitian yang sudah dicantumkan di studi pustaka yang dimana penelitian ini dan penelitian sebelumnya sama-sama mencapai tujuan yaitu membantu dan memudahkan dalam melakukan pembayaran iuran atau SPP.

\section{IMPLEMENTASI}

Adapun implementasi program pada aplikasi Pembayaran Iuran Bulanan pada TPQ As-salam Sumbawa Berbasis Android adalah sebagai berikut :

\subsection{Tampilan Login}

Adapun tampilan login pada aplikasi pembayaran iuran bulanan TPQ As-salam yaitu sebagai berikut : 


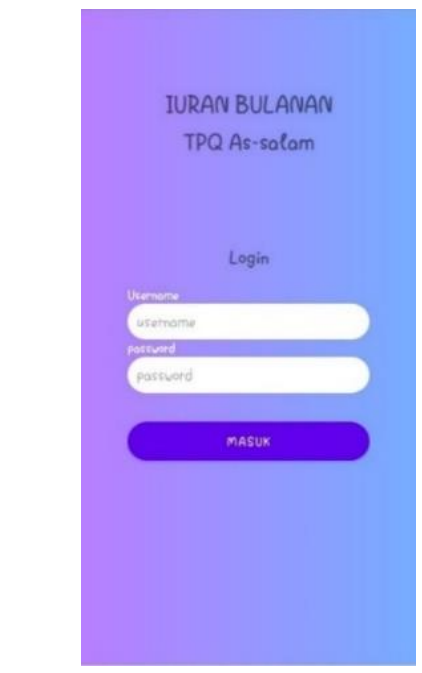

Gambar 6. Tampilan Login

\subsection{Tampilan Aplikasi Admin}

a. Tampilan Admin

Adapun implementasi tampilan admin pada aplikasi pembayaran iuran TPQ As-salam yaitu sebagai berikut :

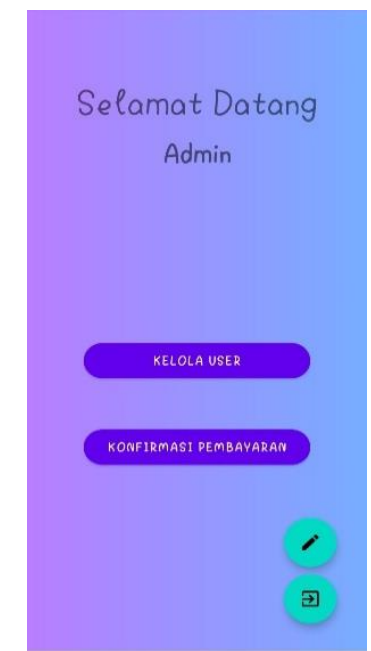

Gambar 7. Tampilan Admin

b. Tampilan Kelola User

Adapun implementasi tampilan kelola user pada aplikasi pembayaran iuran bulanan TPQ As-salam yaitu sebagai berikut :

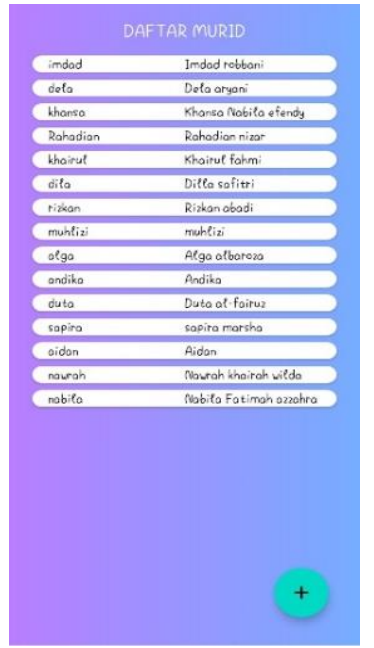

Gambar 8. Tampilan Kelola User 
c. Tampilan Dialog Item Kelola User

Adapun implementasi tampilan dialog item kelola user pada aplikasi pembayaran iuran bulanan TPQ Assalam yaitu sebagai berikut :

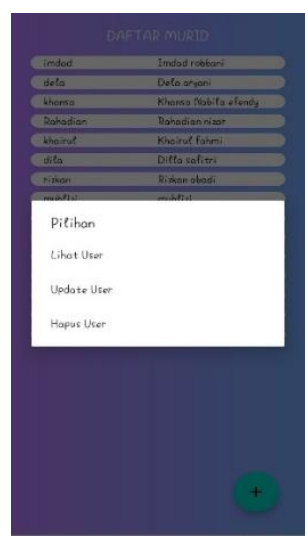

Gambar 9. Tampilan Dialog Item

d. Tampilan Ubah User

Adapun implementasi ubah user pada aplikasi pembayaran iuran bulanan TPQ As-salam yaitu sebagai berikut :

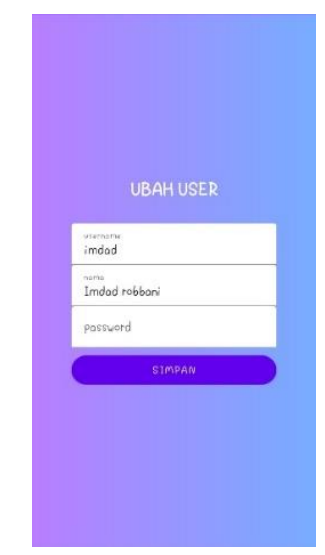

Gambar 10. Ubah User

e. Tampilan Ubah Admin

Adapun implementasi tampilan ubah admin pada aplikasi pembayaran iuran bulanan TPQ As-salam yaitu sebagai berikut :

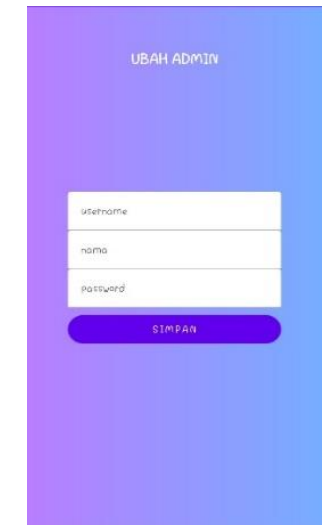

Gambar 11. Ubah Admin

f. Tampilan Lihat User

Adapun implementasi tampilan lihat user pada aplikasi pembayaran iuran bulanan TPQ As-salam yaitu sebagai berikut : 


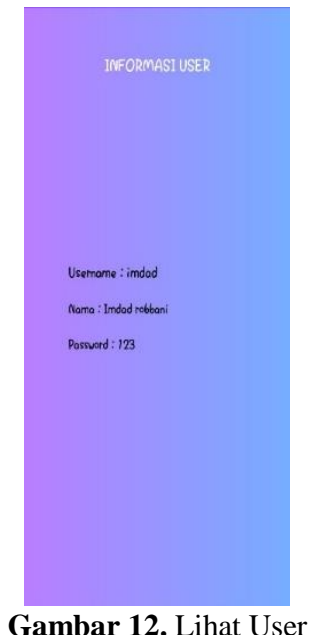

g. Tampilan Daftar Pembayaran

Adapun implementasi tampilan daftar pembayaran pada aplikasi iuran bulanan TPQ As-salam yaitu sebagai berikut :

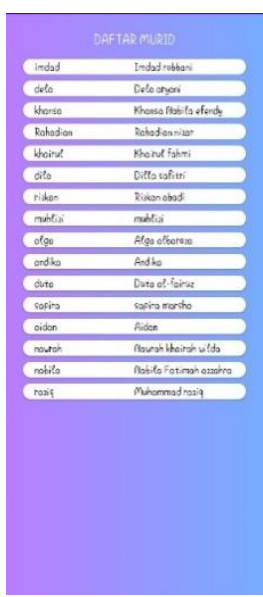

Gambar 13 Daftar Pembayaran

h. Tampilan Riwayat Pembayaran

Adapun implementasi tampilan riwayat pembayaran pada aplikasi iuran bulanan TPQ As-salam yaitu sebagai berikut :

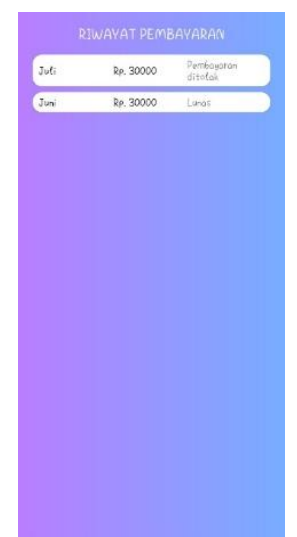

Gambar 14. Tampilan Riwayat Pembayaran

i. Tampilan Konfirmasi Pembayaran

Adapun implementasi tampilan konfirmasi pembayaran iuran bulanan TPQ As-salam yaitu sebagai berikut 


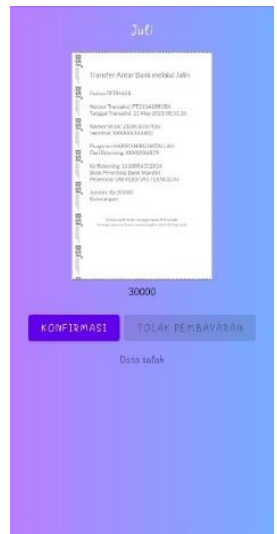

Gambar 15. Tampilan Konfirmasi Pembayaran

j. Tampilan Tambah User

Adapun implementasi tampilan tambah user pada aplikasi pembayaran iuran bulanan TPQ As-salam yaitu sebagai berikut :

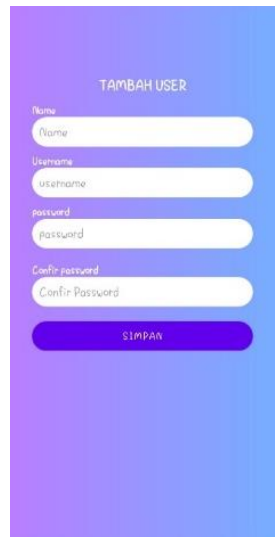

Gambar 16. Tampilan Tambah User

\section{Tampilan Aplikasi User}

a. Tampilan User

Adapun implementasi tampilan aplikasi user pada aplikasi pembayaran iuran bulanan TPQ As-salam yaitu sebagai berikut :

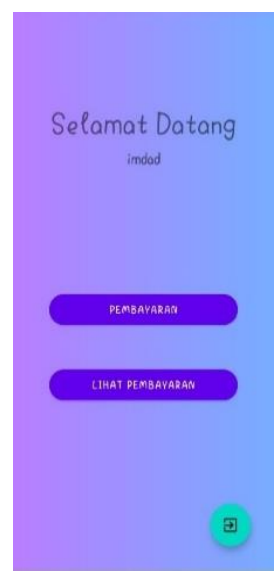

Gambar 17. Tampilan User

b. Tampilan Pembayaran User

Adapun implementasi tampilan pembayaran user pada aplikasi pembayaran iuran bulanan TPQ As-salam yaitu sebagai berikut : 


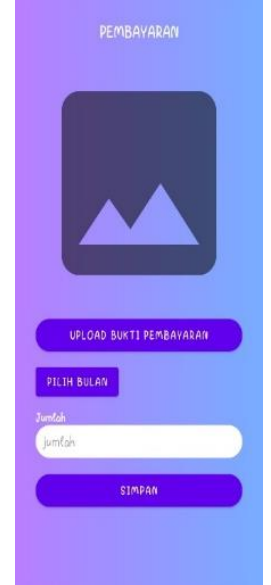

Gambar 18. Tampilan Pembayaran User

\section{KESIMPULAN}

Hasil dari penelitian ini diharapkan dapat membantu memudahkan TPQ As-salam dalam melakukan pembayaran iuran bulanan, mencatat pembayaran dan menyimpan data pembayaran. Aplikasi Pembayaran Iuran Bulanan pada TPQ Assalam Sumbawa Berbasis Android berhasil dibuat dengan bahasa pemograman java dan MySQL sebagai database, data pembayaran akan tersimpan secara otomatis karena menggunakan proses input yang dilakukan secara terkomputerisasi dan data tersimpan di databas.

\section{REFERENCES}

[1] Creswell, J. W. (2015). Research Design Pendekatan Kualitatif, Kuantitatif, dan Mixed. PUSTAKA PELAJAR.

[2] McLeod (2002) Rekayasa perangkat lunak.

[3] Kenneth E.Kendall, J. E. K (2010). Analisis dan perancangan sistem Jilid 1-5/E

[4] Rosa As \& m.shalahuddin. (2011). Modul Pembelajaran Rekayasa Perangkat Lunak Terstruktur Berorientasi Objek.

[5] Nazruddin, H. S. (2012). Pemograman Aplikasi Mobile Smartphone dan Tablet PC Berbasis Android. Penerbit Informatika.

[6] Hutabri, E. (2019). Penerapan Metode Rapid Application Development (RAD) Dalam Perancangan Media Pembelajaran Multimedia. Innovation in Research of Informatics (INNOVATICS), 1(2), 57-62. https://doi.org/10.37058/innovatics.v1i2.932. 